108TH CONGRESS

2D SESSION

S. 2560

To amend chapter 5 of title 17, United States Code, relating to inducement of copyright infringement, and for other purposes.

\title{
IN THE SENATE OF THE UNITED STATES
}

\author{
JUNE 22, 2004
}

Mr. Hatch (for himself, Mr. Leahy, Mr. Frist, Mr. Daschle, Mr. Graham of South Carolina, and Mrs. Boxer) introduced the following bill; which was read twice and referred to the Committee on the Judiciary

\section{A BILL}

To amend chapter 5 of title 17, United States Code, relating to inducement of copyright infringement, and for other purposes.

1 Be it enacted by the Senate and House of Representa-

2 tives of the United States of America in Congress assembled,

\section{SECTION 1. SHORT TITLE.}

4 This Act may be cited as the "Inducing Infringement

5 of Copyrights Act of 2004".

6 SEC. 2. INTENTIONAL INDUCEMENT OF COPYRIGHT INFRINGEMENT.

8 Section 501 of title 17, United States Code, is

9 amended by adding at the end the following: 
1 “ $(\mathrm{g})(1)$ In this subsection, the term 'intentionally in2 duces' means intentionally aids, abets, induces, or pro3 cures, and intent may be shown by acts from which a rea4 sonable person would find intent to induce infringement 5 based upon all relevant information about such acts then 6 reasonably available to the actor, including whether the 7 activity relies on infringement for its commercial viability. 8 "(2) Whoever intentionally induces any violation 9 identified in subsection (a) shall be liable as an infringer. 10 "(3) Nothing in this subsection shall enlarge or di11 minish the doctrines of vicarious and contributory liability 12 for copyright infringement or require any court to unjustly 13 withhold or impose any secondary liability for copyright 14 infringement.". 